\author{
S.Z. Imamaliyeva, I.F. Mehdiyeva, D.B. Taghiyev, M.B. Babanly
}

\title{
Thermodynamic Investigations of The Erbium Tellurides by EMF Method
}

\author{
Institute of Catalysis and Inorganic Chemistry named after acad. M. Nagiyev, Azerbaijan National Academy of Sciences, \\ Baku, Azerbaijan, samira9597a@gmail.com
}

\begin{abstract}
The work presents the results of a thermodynamic study of the Er-Te system by the method of electromotive forces (EMF) in the temperature range of $300-450 \mathrm{~K}$. From the EMF measurements of the concentration cells relative to the $\mathrm{Er}$ and ErTe electrodes, the partial thermodynamic functions of ErTe and Er in the alloys are determined, based on which the standard thermodynamic formation functions and the standard entropies of the intermediate compounds $\mathrm{ErTe}_{3}, \mathrm{Er}_{2} \mathrm{Te}_{3}$, and ErTe are calculated. A comparative analysis of the obtained data with the literature is carried out.
\end{abstract}

Keywords: phase diagram, erbium tellurides, EMF method, thermodynamic functions.

Received 14 May, 2020; Accepted 15 June 2020.

\section{Introduction}

The rare-earth chalcogenides are a promising functional class of materials due to their unusual electronic [1-3], thermoelectric [3-5], magnetic [6-8], optical and magneto-optical properties [9-11], and have found their practical application in spintronics and highperformance computing $[12,13]$.

In order to create and optimize modern methods for controlled synthesis of novel complex materials based on rare earth chalcogenides, it is necessary to investigate phase equilibria and thermodynamic properties of the respective systems [14-17].

$\mathrm{Er}-\mathrm{Te}$ system is characterized by the formation of ErTe, $\mathrm{Er}_{2} \mathrm{Te}_{3}$ and $\mathrm{ErTe}_{3}[18,19]$. ErTe and $\mathrm{Er}_{2} \mathrm{Te}_{3}$ compounds melt congruently at 1773 and $1486 \mathrm{~K}$, while $\mathrm{ErTe}_{3}$ melts at $957 \mathrm{~K}$ with decomposition according to the peritectic reaction $\mathrm{Er}_{2} \mathrm{Te}_{3}+\mathrm{L} \leftrightarrow \mathrm{ErTe}_{3}$. ErTe and $\mathrm{Er}_{2} \mathrm{Te}_{3}$ have a cubic, ErTe ${ }_{3}$ - rhombic structure.

The thermodynamic properties of erbium tellurides are poorly understood and fragmented. The heat of the formation of $\mathrm{Er}_{2} \mathrm{Te}_{3}$ compound was determined by the authors of [22] using the calorimetric measurements. In a later work [23], the standard thermodynamic functions of the formation of $\mathrm{Er}_{2} \mathrm{Te}_{3}$ and $\mathrm{ErTe}_{2.85}$ were calculated by using the electromotive force (EMF) method in the temperature interval 573-723 K. The estimated data on the standard enthalpy of formation and entropy of ErTe and $\mathrm{Er}_{2} \mathrm{Te}_{3}$ are given in the handbook [24].

The author [25] obtained the thermodynamic functions of the formation of a number of $\mathrm{Ln}_{2} \mathrm{Te}_{3}$ ( $\mathrm{Ln}$ rare earth elements) compounds. They used a combination of the EMF method with low- temperature heat capacity measurements and the tetrad-effect phenomenon. The results obtained showed that they can be used for estimation of the thermodynamic functions of lanthanide tellurides. In a little later paper [26], the same authors using the above combination method presented thermodynamic data for a number of rare-earth chalcogenides.

In a recently published work [27], based on the data on the standard heat of formation of $\mathrm{Er}_{2} \mathrm{Te}_{3}$ [22], its standard thermodynamic functions were calculated, which were then used to calculate the standard thermodynamic functions of ErTe by the EMF method.

This paper presents the results of the study of the ErTe system in the compositions area $>50$ at $\%$ Te by the EMF method with glycerol electrolyte

This modification of the EMF method was successfully used for thermodynamic studies of a number of binary and ternary chalcogenide systems [28-34]. 


\section{Experimental}

For the thermodynamic investigations of the intermediate phases of the Er-Te system, the following concentration cell was assembled:

(-) $\operatorname{ErTe}\left(\right.$ s.) $\mid$ glycerin $+\mathrm{KCl}+\mathrm{ErCl}_{3} \mid(\mathrm{Er}$ in alloy) (s.) (+) (1)

and their EMF were measured in the temperature range $300-450 \mathrm{~K}$.

In cells of type (1), a saturated glycerol solution of $\mathrm{KCl}$ with the addition of 0.1 mass $\% \mathrm{ErCl}_{3}$ was used as an electrolyte. Since the electrolyte should not contain moisture and oxygen, glycerol (analytical grade) was thoroughly dried and degassed by evacuation at $\sim 450 \mathrm{~K}$, and anhydrous, chemically pure $\mathrm{KCl}$ and $\mathrm{ErCl}_{3}$ were used. Erbium monotelluride with a slight excess of tellurium (ErTe $\mathrm{E}_{1.01}$ composition) was used as the reference electrode (cathode), while equilibrated alloys of the Er-Te system were used as right electrodes (anodes).

The detailed descriptions of the methods for the preparation of the electrodes and electrolyte and assembly of the electrochemical cell were described in [34-37].

ErTe and alloys - the right electrodes were synthesized by the ceramic method by melting of elementary components of high purity in evacuated $\left(10^{-2} \mathrm{~Pa}\right)$ silica ampoules at $1000 \mathrm{~K}$. To prevent the interaction of erbium with the inner walls of quartz, the synthesis was carried out in graphitized ampoules. To achieve a state as close to equilibrium as possible, after melting the intermediate samples were ground into powder, mixed, pressed into cylindrical tablets, and then annealed at $550 \mathrm{~K}(1000 \mathrm{~h})$, and at $450 \mathrm{~K}(300 \mathrm{~h})$. The phase composition was controlled by powder X-ray diffraction analysis (PXRD) (Fig. 1). For example, Fig.1 shows a powder X-ray diffraction pattern of an alloy from $\mathrm{Er}_{2} \mathrm{Te}_{3}+\mathrm{ErTe}_{3}$ two-phase area.

In order to prepare the electrodes, the annealed alloys (erbium monotelluride) were ground into a fine powder and were pressed into cylindrical pellets $(8 \mathrm{~mm}$ in diameter and $3-4 \mathrm{~mm}$ in thickness) under the pressure of $\sim 0.1 \mathrm{GPa}$ in a molybdenum current leads (thickness $\sim 0.5 \mathrm{~mm}$ ).

The EMF measurements were accomplished by the Keihtley Model 193 digital voltmeter with an internal resistance of $10^{14} \mathrm{Ohm}$ and accuracy $\pm 0.1 \mathrm{mV}$. The measurements were carried out by heating and cooling the cell in steps of no more than $10 \mathrm{~K}$. The temperature of the electrochemical cell was measured with a chromelalumel thermocouple and a mercury thermometer with an accuracy of $0.5 \mathrm{~K}$. The chromel-alumel thermocouple was pre-calibrated in the temperature range $300-510 \mathrm{~K}$ based on the melting points of elemental gallium $(302.9 \mathrm{~K})$, sulfur $(386 \mathrm{~K})$, indium $(429.7 \mathrm{~K})$ and tin (505 K).

The first equilibrium EMF values were obtained after holding the cell at $\sim 350 \mathrm{~K}$ for $40-60 \mathrm{~h}$, while the subsequent EMF values were obtained after $3-4 \mathrm{~h}$ when reaching the desired temperature. The system was considered to be in equilibrium if the EMF measurements were constant or their variations were not significant $(<0.3 \mathrm{mV})$ regardless of the direction of the temperature change at repeated measurements at a given temperature. The reversibility of the assembled cell and the reproducibility of the results were controlled by checking the mass and PXRD analysis of the selected electrodes before and after the measurements.

In order to control the reproducibility of the cell, for each sample, EMF was measured 2 - 3 times at two constant temperatures within the experiment. Table 1

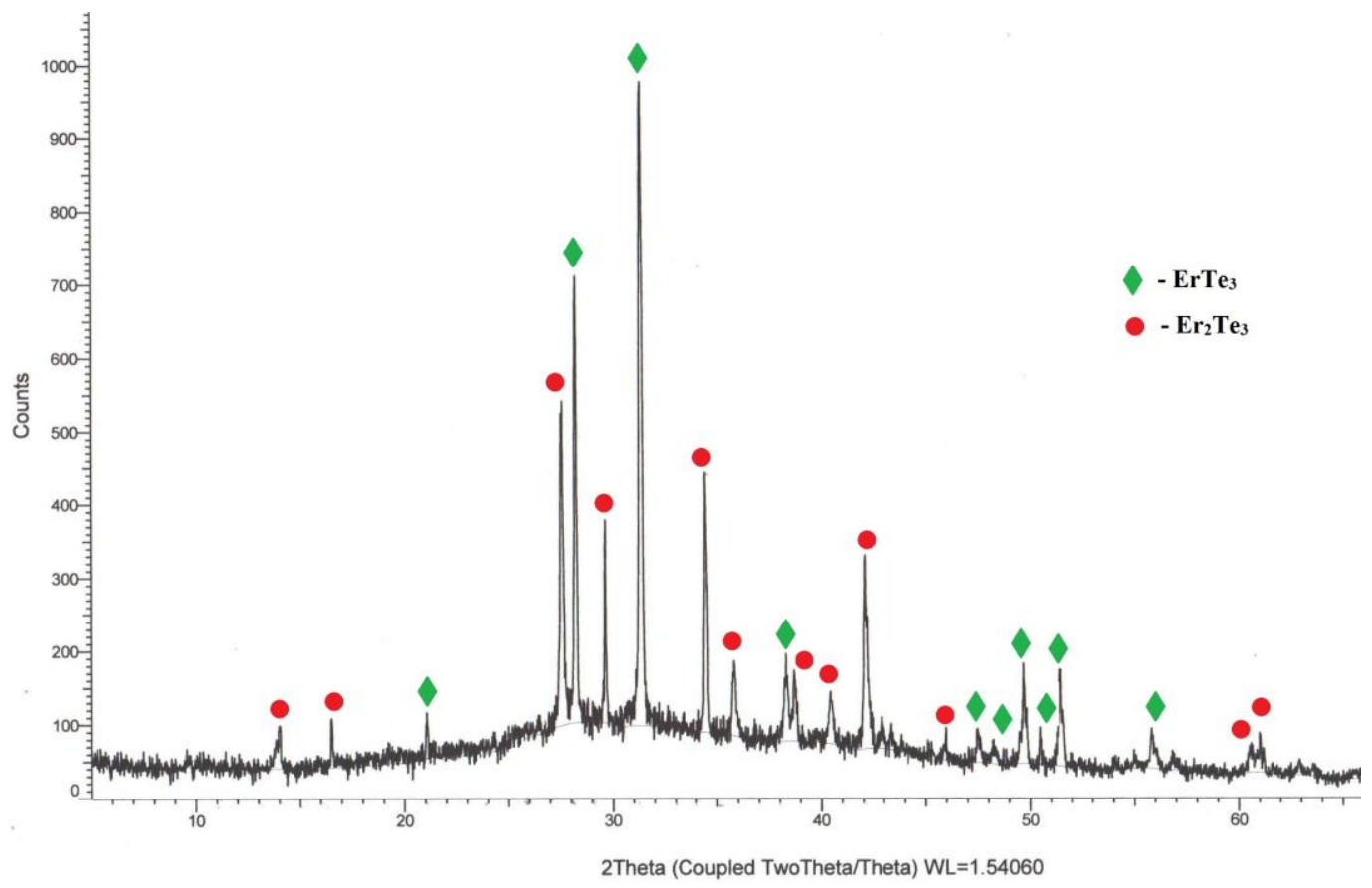

Fig.1. The powder X-ray diffraction pattern of an alloy from $\mathrm{Er}_{2} \mathrm{Te}_{3}+\mathrm{ErTe}_{3}$ two-phase area. 
Experimentally obtained data for temperature $\left(\mathrm{T}_{\mathrm{i}}\right)$ and $\operatorname{EMF}\left(\mathrm{E}_{\mathrm{i}}\right)$ and data associated with the calculation steps for the $\mathrm{ErTe}_{3}+\mathrm{Te}$ phase region of the Er-Te system

\begin{tabular}{|c|c|c|c|c|c|c|c|}
\hline $\mathrm{T}_{\mathrm{i}}, \mathrm{K}$ & $\mathrm{E}_{\mathrm{i}}, \mathrm{MB}$ & $\mathrm{T}_{\mathrm{i}}-\overline{\mathrm{T}}$ & $\mathrm{E}_{\mathrm{i}}\left(\mathrm{T}_{\mathrm{i}}-\overline{\mathrm{T}}\right)$ & $\left(\mathrm{T}_{\mathrm{i}}-\overline{\mathrm{T}}\right)^{2}$ & $\tilde{\mathrm{E}}$ & $\mathrm{E}_{\mathrm{i}}-\tilde{\mathrm{E}}$ & $\left(E_{i}-\tilde{E}\right)^{2}$ \\
\hline 302.3 & 459.46 & -68.32 & -31390.31 & 4667.62 & 459.52 & -0.06 & 0.00 \\
\hline 306.4 & 459.59 & -64.22 & -29514.87 & 4124.21 & 459.76 & -0.17 & 0.03 \\
\hline 311.2 & 459.53 & -59.42 & -27305.27 & 3530.74 & 460.05 & -0.52 & 0.27 \\
\hline 316.3 & 459.62 & -54.32 & -24966.56 & 2950.66 & 460.36 & -0.74 & 0.54 \\
\hline 319.3 & 461.07 & -51.32 & -23662.11 & 2633.74 & 460.53 & 0.54 & 0.29 \\
\hline 324.8 & 460.11 & -45.82 & -21082.24 & 2099.47 & 460.86 & -0.75 & 0.57 \\
\hline 329 & 462.45 & -41.62 & -19247.17 & 1732.22 & 461.11 & 1.34 & 1.78 \\
\hline 333.1 & 461.92 & -37.52 & -17331.24 & 1407.75 & 461.36 & 0.56 & 0.31 \\
\hline 335.9 & 462.07 & -34.72 & -16043.07 & 1205.48 & 461.53 & 0.54 & 0.30 \\
\hline 338.2 & 462.82 & -32.42 & -15004.62 & 1051.06 & 461.66 & 1.16 & 1.34 \\
\hline 342.9 & 460.87 & -27.72 & -12775.32 & 768.40 & 461.94 & -1.07 & 1.15 \\
\hline 347.1 & 463.12 & -23.52 & -10892.58 & 553.19 & 462.20 & 0.92 & 0.86 \\
\hline 352.2 & 463.41 & -18.42 & -8536.01 & 339.30 & 462.50 & 0.91 & 0.83 \\
\hline 356.6 & 463.51 & -14.02 & -6498.27 & 196.56 & 462.76 & 0.74 & 0.54 \\
\hline 362.1 & 462.69 & -8.52 & -3942.12 & 72.59 & 463.09 & -0.40 & 0.16 \\
\hline 369.4 & 462.38 & -1.22 & -564.10 & 1.49 & 463.53 & -1.15 & 1.32 \\
\hline 375.9 & 463.19 & 5.28 & 2445.64 & 27.88 & 463.92 & -0.73 & 0.53 \\
\hline 380.2 & 463.26 & 9.58 & 4438.03 & 91.78 & 464.17 & -0.91 & 0.83 \\
\hline 387.5 & 464.55 & 16.88 & 7841.60 & 284.93 & 464.61 & -0.06 & 0.00 \\
\hline 392.2 & 464.96 & 21.58 & 10033.84 & 465.70 & 464.89 & 0.07 & 0.01 \\
\hline 398.1 & 464.35 & 27.48 & 12760.34 & 755.15 & 465.24 & -0.89 & 0.79 \\
\hline 404.6 & 464.53 & 33.98 & 15784.73 & 1154.64 & 465.63 & -1.10 & 1.21 \\
\hline 410.2 & 464.77 & 39.58 & 18395.60 & 1566.58 & 465.96 & -1.19 & 1.43 \\
\hline 415.7 & 466.72 & 45.08 & 21039.74 & 2032.21 & 466.29 & 0.43 & 0.18 \\
\hline 420.9 & 466.99 & 50.28 & 23480.26 & 2528.08 & 466.60 & 0.39 & 0.15 \\
\hline 425.1 & 467.28 & 54.48 & 25457.41 & 2968.07 & 466.85 & 0.43 & 0.18 \\
\hline 432.7 & 468.11 & 62.08 & 29060.27 & 3853.93 & 467.31 & 0.80 & 0.64 \\
\hline 437.3 & 468.22 & 66.68 & 31220.91 & 4446.22 & 467.58 & 0.64 & 0.41 \\
\hline 442.8 & 468.21 & 72.18 & 33795.40 & 5209.95 & 467.91 & 0.30 & 0.09 \\
\hline 448.6 & 468.25 & 77.98 & 36514.14 & 6080.88 & 468.26 & -0.01 & 0.00 \\
\hline $\bar{T}=370.62$ & $\overline{\mathrm{E}}=463.60$ & & & & & & \\
\hline
\end{tabular}

presents their averaged values. Experimentally obtained data for temperature $\left(\mathrm{T}_{\mathrm{i}}\right)$ and $\operatorname{EMF}\left(\mathrm{E}_{\mathrm{i}}\right)$ and data associated with the calculation steps for the $\mathrm{ErTe}_{3}+\mathrm{Te}$ phase area are listed in Table 1.

\section{Results and discussion}

The analysis of EMF measurements showed their reproducibility. For two studied samples from each phase region, the measurement data were practically identical while their temperature dependences were linear (Fig. 2).
This indicates the constancy of the phase compositions of electrodes in the temperature range of EMF measurements and allows us to make thermodynamic calculations [37].

The EMF measurements were processed by the leastsquares method [45] on the assumption of a linear relationship of the EMF vs temperature and were expressed by the equation

$$
E=a+b T \pm t\left[\frac{S_{\mathrm{E}}^{2}}{\mathrm{n}}+\frac{S_{\mathrm{E}}^{2}(\mathrm{~T}-\overline{\mathrm{T}})^{2}}{\sum\left(\mathrm{T}_{\mathrm{i}}-\overline{\mathrm{T}}\right)^{2}}\right]^{\frac{1}{2}},
$$




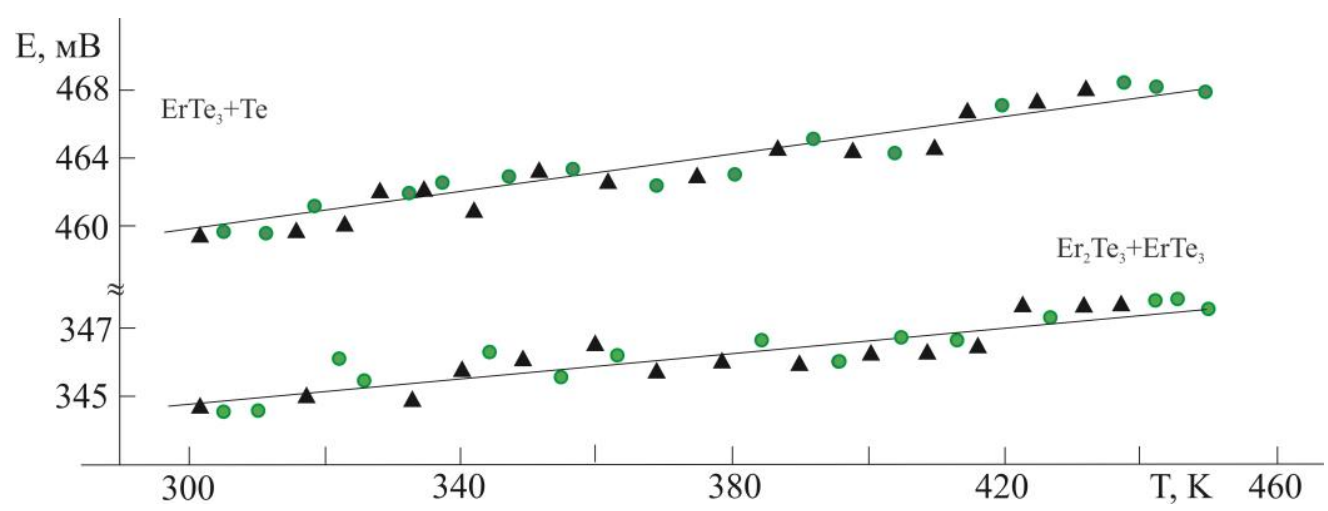

Fig. 2. EMF dependencies upon temperature for alloys of the $\mathrm{ErTe}_{3}+\mathrm{Te}$ and $\mathrm{Er}_{2} \mathrm{Te}_{3}+\mathrm{ErTe}_{3}$ phase areas of the Er-Te system. Green circles and black triangles indicate alloys of various compositions in a given phase region.

Table 2

Relations between the EMF and the temperature for type (1) cells in some phase regions of the Er-Te system in the 300-450 K temperature interval

\begin{tabular}{|c|c|}
\hline Phase region & $\mathrm{E}, \mathrm{MB}=\mathrm{a}+\mathrm{bT} \pm 2\left[\delta_{\mathrm{E}}^{2} / \mathrm{n}+\delta_{\mathrm{b}}^{2}(\mathrm{~T}-\overline{\mathrm{T}})\right]^{1 / 2}$ \\
\hline $\mathrm{ErTe}_{3}+\mathrm{Te}$ & $441.4+0.0597 \mathrm{~T} \pm 2\left[\frac{0.60}{30}+1.02 \cdot 10^{-6}(\mathrm{~T}-370.62)^{2}\right]^{1 / 2}$ \\
\hline $\mathrm{Er}_{2} \mathrm{Te}_{3}+\mathrm{ErTe}_{3}$ & $338.9+0.0193 \mathrm{~T} \pm 2\left[\frac{0.44}{30}+6.86 \cdot 10^{-6}(\mathrm{~T}-377.14)^{2}\right]^{1 / 2}$ \\
\hline
\end{tabular}

Table 3

Relative partial functions of erbium monotelluride in the alloys of the Er-Te system at T $=298 \mathrm{~K}$

\begin{tabular}{|c|c|c|c|}
\hline \multirow{2}{*}{ Phase region } & $-\Delta \overline{\mathrm{G}}_{\mathrm{ErTe}}$ & \multicolumn{1}{|c|}{$-\Delta \overline{\mathrm{H}}_{\mathrm{ErTe}}$} & \multicolumn{1}{c|}{$\overline{\mathrm{S}}_{\mathrm{ErTe}}$} \\
\cline { 2 - 4 } & \multicolumn{2}{|c|}{$\mathrm{KJ} \cdot \mathrm{mol}^{-1}$} & $\mathrm{KJ} \cdot \mathrm{mol}^{-1} \cdot \mathrm{K}^{-1}$ \\
\hline $\mathrm{ErTe}_{3}+\mathrm{Te}$ & $132.94 \pm 0.16$ & $127.79 \pm 0.69$ & $17.29 \pm 1.85$ \\
\hline $\mathrm{Er}_{2} \mathrm{Te}_{3}+\mathrm{ErTe}_{3}$ & $99.78 \pm 0.14$ & $98.11 \pm 0.58$ & $5.6 \pm 1.52$ \\
\hline
\end{tabular}

where $\mathrm{a}$ and $\mathrm{b}$ are empirical constants; $\mathrm{n}$ is the number of pairs of $\mathrm{T}$ and $\mathrm{E}$ values; $\mathrm{S}_{\mathrm{E}}$ is the error variance of the EMF measurements; $T$ is the average of the absolute temperature; $\mathrm{t}$ is the Student's test. At the confidence level of $95 \%$ and $n=30$, the Student's test is $t \leq 2$.

The obtained equations of the type (2) are listed in Table 2.

From obtained relations by using the thermodynamic expressions [36, 37]:

$$
\begin{gathered}
\Delta \overline{\mathrm{G}}_{\mathrm{ErTe}}=-\mathrm{zFE} \\
\Delta \overline{\mathrm{S}}_{\mathrm{ErTe}}=\mathrm{zF}\left(\frac{\partial \mathrm{E}}{\partial \mathrm{T}}\right)_{\mathrm{P}}=\mathrm{zFb}, \\
\Delta \overline{\mathrm{H}}_{\mathrm{ErTe}}=-\mathrm{zF}\left[\mathrm{E}-\mathrm{T}\left(\frac{\partial \mathrm{E}}{\partial \mathrm{T}}\right)_{\mathrm{P}}\right]=-\mathrm{zFa},
\end{gathered}
$$

the partial molar Gibbs free energy, enthalpy, and entropy of erbium monotelluride in alloys were calculated (Table 3). Here, z-is the number of electrons, participating in the electrochemical reaction, in our case $\mathrm{Z}=3 ; \mathrm{F}$ is the Faraday constant $(\mathrm{F}=96485.34 \mathrm{C} / \mathrm{mol})$.

The data presented in Table 3 are in accordance with

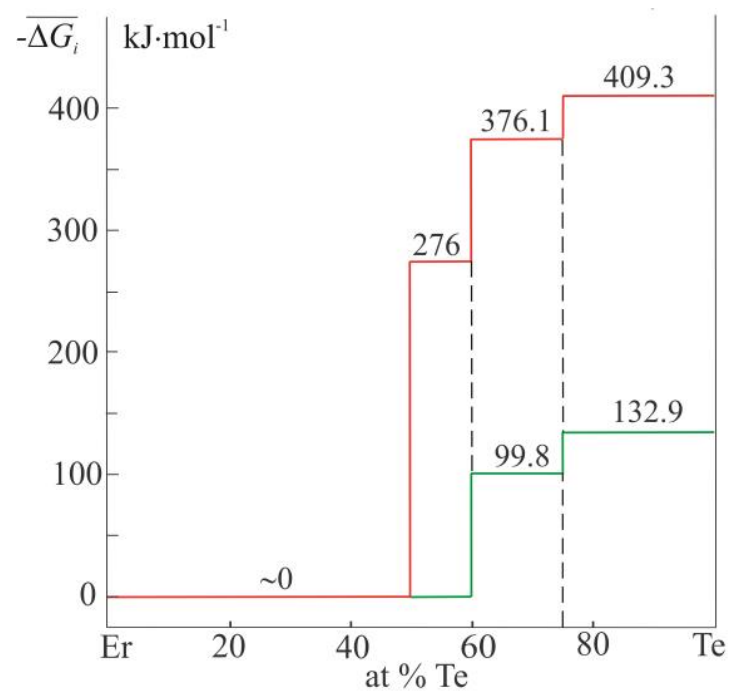

Fig. 3. The dependencies of the partial free Gibbs energies of ErTe (green line) and Er (red line) on the composition in Er-Te alloys at $298 \mathrm{~K}$. 
the phase diagram of the Er-Te system [18]. As can be seen from Fig. 3, at a constant temperature, the partial Gibbs free energy of ErTe is constant within the twophase region and changes stepwise upon transition from one region to another.

These values are the differences between the corresponding partial molar functions of erbium for the right and left electrodes of cells (1). For example,

$$
\Delta \bar{Z}_{\mathrm{ErTe}}=\Delta \overline{\mathrm{Z}}_{\mathrm{Er}}(\text { Er in Te rich alloy })-\Delta \bar{Z}_{\mathrm{Er}}(\mathrm{ErTe})
$$

here $\mathrm{Z} \equiv \mathrm{G}$ or $\mathrm{H}$. Therefore, the partial thermodynamic functions of erbium in studied phase areas, can be calculated using the relation:

$$
\Delta \overline{\mathrm{Z}}(\mathrm{Er} \text { in alloys })=\Delta \overline{\mathrm{Z}}_{\mathrm{Er}}(\mathrm{ErTe})+\Delta \overline{\mathrm{Z}}_{\mathrm{ErTe}}
$$

In order to calculate the partial thermodynamic functions of erbium in alloys $\mathrm{ErTe}_{3}+\mathrm{Te}$ and $\mathrm{Er}_{2} \mathrm{Te}_{3}+\mathrm{ErTe}_{3}$, we summarized the data of Table 3 with the corresponding partial molar functions of Er in ErTe [27] (Table 4). The results are shown in Table 4.

According to the phase diagram [18], the partial molar thermodynamic values of erbium in compounds are the thermodynamic characteristics of the following potential formation reactions (the substances in the crystalline state):

$$
\begin{gathered}
\mathrm{Er}+3 \mathrm{Te}=\mathrm{ErTe}_{3} \\
\mathrm{Er}+3 \mathrm{ErTe}_{3}=2 \mathrm{Er}_{2} \mathrm{Te}_{3} \\
\mathrm{Er}+\mathrm{Er}_{2} \mathrm{Te}_{3}=3 \mathrm{ErTe}^{2}
\end{gathered}
$$

Thus, the standard thermodynamic functions of formation of erbium tellurides were calculated by using the relations (7)-(9) :

$$
\begin{gathered}
\Delta_{\mathrm{f}} \mathrm{Z}^{0}\left(\mathrm{ErTe}_{3}\right)=\Delta \overline{\mathrm{Z}}_{\mathrm{Er}} \\
2 \Delta_{\mathrm{f}} \mathrm{Z}^{0}\left(\mathrm{Er}_{2} \mathrm{Te}_{3}\right)=\Delta \overline{\mathrm{Z}}_{\mathrm{Er}}+\Delta \mathrm{Z}^{0}\left(\mathrm{ErTe}_{3}\right) \\
3 \Delta_{\mathrm{f}} \mathrm{Z}^{0}(\mathrm{ErTe})=\Delta \overline{\mathrm{Z}}_{\mathrm{Er}}+\Delta \mathrm{Z}^{0}\left(\mathrm{Er}_{2} \mathrm{Te}_{3}\right)
\end{gathered}
$$

while the standard entropies were calculated as:

$$
\begin{gathered}
\mathrm{S}^{0}\left(\mathrm{ErTe}_{3}\right)=\left[\Delta \overline{\mathrm{S}}_{\mathrm{Er}}+\mathrm{S}^{0}(\mathrm{Er})\right]+3 \mathrm{~S}^{0}(\mathrm{Te}) \\
2 \mathrm{~S}^{0}\left(\mathrm{Er}_{2} \mathrm{Te}_{3}\right)=\left[\Delta \overline{\mathrm{S}}_{\mathrm{Er}}+\mathrm{S}^{0}(\mathrm{Er})\right]+3 \mathrm{~S}^{0}(\mathrm{Te}) \\
3 \mathrm{~S}^{0}(\mathrm{ErTe})=\left[\Delta \overline{\mathrm{S}}_{\mathrm{Er}}+\mathrm{S}^{0}(\mathrm{Er})\right]+\mathrm{S}^{0}(\mathrm{Te})
\end{gathered}
$$

For the thermodynamic calculations, in addition to own experimental data (Table 3), we used the literature data [21] on the standard entropies of elementary erbium $\left(73.14 \pm 0.63 \mathrm{~J} \cdot \mathrm{mol}^{-1} \cdot \mathrm{K}^{-1}\right) \quad$ and tellurium $\left(49.5 \pm 0.2 \mathrm{~J} \cdot \mathrm{mol}^{-1} \cdot \mathrm{K}^{-1}\right)$. These values are close to the values given in other modern handbooks [20, 39, 40]. The obtained sets of standard integral thermodynamic functions of erbium tellurides are summarized in Table 5. In all cases, the estimated standard uncertainties were calculated by accumulating the errors.

A comparison of our results for $\mathrm{Er}_{2} \mathrm{Te}_{3}$ with the data of [23], carried out by the EMF method in the temperature range $580-720 \mathrm{~K}$, shows their satisfactory compliance. If the results of [23] for $\mathrm{ErTe}_{2.85}$ are converted to the formula unit $\mathrm{ErTe}_{3}$, then we obtain the values $\left(-\Delta_{\mathrm{f}} \mathrm{G}^{0}(298 \mathrm{~K})=414.3, \quad-\Delta_{\mathrm{f}} \mathrm{H}^{0}(298 \mathrm{~K})=\right.$ $412.3 \mathrm{~kJ} \cdot \mathrm{mol}^{-1}$ ) closer to our data. The calorimetric data on the standard heat of formation of $\mathrm{Er}_{2} \mathrm{Te}_{3}$ [22] are significantly higher than all other available data, including the estimated values given in the handbook [24]. For $\mathrm{Er}_{2} \mathrm{Te}_{3}$, our data practically coincide with the calculated data [25]. Despite the same values of the partial molar values of erbium, some discrepancies of our results for ErTe and data of [27] should be noted. This is because the author [27], for calculations of the integral thermodynamic functions for ErTe, used the results of [22] for the $\mathrm{Er}_{2} \mathrm{Te}_{3}$ compound, while we used our data (Table 5).

Relative partial functions of erbium in the alloys of the Er-Te system at T $=298 \mathrm{~K}$

\begin{tabular}{|c|c|c|c|}
\hline \multirow{2}{*}{ Phase region } & $-\Delta \overline{\mathrm{G}}_{\mathrm{Er}}$ & $-\Delta \overline{\mathrm{H}}_{\mathrm{Er}}$ & $\Delta \overline{\mathrm{S}}_{\mathrm{Er}}$ \\
\cline { 2 - 4 } & \multicolumn{2}{|c|}{$\mathrm{KJ} \cdot \mathrm{mol}^{-1}$} & $\mathrm{KJ} \cdot \mathrm{mol}^{-1} \cdot \mathrm{K}^{-1}$ \\
\hline $\mathrm{ErTe}_{3}+\mathrm{Te}$ & $409.3 \pm 0.28$ & $411.38 \pm 1.29$ & $-6.97 \pm 2.51$ \\
\hline $\mathrm{Er}_{2} \mathrm{Te}_{3}+\mathrm{ErTe}_{3}$ & $376.14 \pm 0.26$ & $381.7 \pm 1.18$ & $-18.65 \pm 2.18$ \\
\hline $\mathrm{ErTe}_{3}+\mathrm{ErTe}[27]$ & $276.36 \pm 0.12$ & $283.59 \pm 0.60$ & $-24.25 \pm 0.66$ \\
\hline
\end{tabular}

Table 5

Standard integral thermodynamic functions of erbium tellurides at temperature $\mathrm{T}=298 \mathrm{~K}$

\begin{tabular}{|c|c|c|c|}
\hline \multirow{2}{*}{ Compound } & $-\Delta_{\mathrm{f}} \mathrm{G}^{0}(298 \mathrm{~K})$ & $-\Delta_{\mathrm{f}} \mathrm{H}^{0}(298 \mathrm{~K})$ & $\mathrm{S}_{298}^{0}$ \\
\cline { 2 - 4 } & \multicolumn{2}{|c|}{$\mathrm{KJ}^{2} \mathrm{~mol}^{-1}$} & $\mathrm{KJ} \cdot \mathrm{mol}^{-1} \cdot \mathrm{K}^{-1}$ \\
\hline $\mathrm{ErTe}_{3}$ & $409.3 \pm 0.3$ & $411.4 \pm 1.3$ & $214.7 \pm 3.7$ \\
\hline $\mathrm{ErTe}_{2.85}$ & $392.4 \pm 0.5[23]$ & $391.7 \pm 4.8[23]$ & - \\
\hline \multirow{3}{*}{$\mathrm{Er}_{2} \mathrm{Te}_{3}$} & $784.4 \pm 0.5$ & $793.1 \pm 2.5$ & $269.2 \pm 6.5$ \\
\cline { 2 - 4 } & $797.2 \pm 1[23]$ & $822.2 \pm 16.7[23]$ & - \\
\cline { 2 - 4 } & $782.5 \pm 10[25]$ & $795.5 \pm 10[25]$ & $256.1 \pm 10[25,26]$ \\
\cline { 2 - 4 } & & $856 \pm 25[22]$ & $262[24]$ \\
\cline { 2 - 4 } & & $816 \pm 120[24]$ & $86.7 \pm 9.3[27]$ \\
\hline \multirow{3}{*}{ ErTe } & $353.6 \pm 0.3$ & $358.9 \pm 0.6$ & $97 \pm 12[24]$ \\
\hline
\end{tabular}




\section{Conclusions}

Based on the EMF measurements in the temperature range $300-450 \mathrm{~K}$, we obtained new data set on the partial molar functions of erbium and erbium telluride in Er-Te system. By combining these data, the standard thermodynamic functions of formation and the standard entropies of ErTe, $\mathrm{Er}_{2} \mathrm{Te}_{3}$, and $\mathrm{ErTe}_{3}$ compounds are calculated. A comparative analysis of obtained mutually consistent data sets on standard integral thermodynamic functions with the available mismatch literary data is done. This is the first mutually agreed dataset for each of the compounds studied and for the Er-Te system as a whole.

\section{Acknowledgment}

The work has been carried out within the framework of the international joint research laboratory "Advanced Materials for Spintronics and Quantum Computing”
(AMSQC) established between Institute of Catalysis and Inorganic Chemistry of ANAS (Azerbaijan) and Donostia International Physics Center (Basque Country, Spain) and partially supported by the Science Development Foundation under the President of the Republic of Azerbaijan, a grant EIF/MQM/Elm-Tehsil-1-2016-1(26)71/01/4-M-33.

Imamaliyeva S.Z. - $\mathrm{PhD}$ on Chemistry, Associate Professor, Senior Researcher of 'Thermodynamics of functional inorganic compounds' laboratory;

Mehdiyeva I.F. - graduate student, researcher of "Thermodynamics of functional inorganic compounds" laboratory;

Taghiyev D.B. - Academician, Doctor on Chemistry, Director of ICIC;

Babanly M.B. - Corresponding member, Doctor on Chemistry, Deputy- Director of ICIC.

[1] A.R. Jha. Rare Earth Materials: Properties and Applications (CRC Press, United States, 2014).

[2] Y. Sc, La-Lu, Gmelin Handbock of lnorganic Chemistry, in: Hartmut Bergmann (Ed.), Rare Earth Elements, 8th Edition (Springer-Verlag Heidelberg GmbH, Berlin, 1987).

[3] T.Vo, P. von Allmen, C.-H. Huang, J.M.Ma, S.K. Bux, J.-P. Fleurial, Appl. Phys. 116, 133701 (2014) (https://doi.org/10.1063/1.4896670).

[4] D. Cheikh, B.E. Hogan, T. Vo, P von Allmen, K. Lee, D.M. Smiadak, A. Zevalkink, B.S. Dunn, J.-P. Fleurial, S.K. Bux, Joule 2, 698 (2018) (https://doi.org/10.1016/j.joule.2018.01.013).

[5] A.F. May, J.-P. Fleurial, G.J. Snyder, Phys. Rev. B $78, \quad 125205$ (https://doi.org/10.1103/PhysRevB.78.125205).

[6] I.P. Muthuselvam, R. Nehru, K.R. Babu, K. Saranya, S.N. Kaul, S-M. Chen, W-T. Chen, Y. Liu, G-Y Guo, F. Xiu, R. Sankar, J. Physics: Condensed Matter. 31(28), 285802 (2019) (https://doi.org/10.1088/1361648X/ab1570).

[7] M. Saint-Paul, P. Monceau, Advances in Condensed Matter Physics (4), 1 (2019) (https://doi.org/10.1155/2019/2138264).

[8] M.D. Regulacio, K. Bussmann, B. Lewis, S.L. Stoll, Journal of the American Chemical Society 128(34), 11173 (2006) (https://doi.org/10.1021/ja0620080).

[9] Q.H. Li, X. Jin, Y. Yang, H.N. Wang, H.J. Xu, Y.Y. Cheng, T.H. Wei, Y.C. Qin, X.B. Luo, W.F. Sun, S.L. Luo, Adv. Funct. Mater 26(2), 254 (2016) (https://doi.org/10.1002/adfm.201503433).

[10] P. Wachter. Critical reviewers in solid state and materials sciences 3(2), 189 (1972) (https://doi.org/10.1080/10408437208244865).

[11] A.S. Verma, African Phys.Rev. 3, 11 (2009).

[12] M.A. Kuroda, Z. Jiang, M. Povolotskyi, G. Klimeck, D.M. Newns, G.J. Martyna, Physical Review B 90, 245124 (2014) (https://doi.org/10.1103/PhysRevB.90.245124).

[13] A.T. Filip, P. LeClair, C.J.P. Smits, J.T. Kohlhepp, H.J.M. Swagten, B. Koopmans, and W.J.M. de Jonge, Appl. Phys. Lett 81, 1815 (2002) (https://doi.org/10.1063/1.1503406).

[14] O.V. Andreev, V.G. Bamburov, L.N. Monina, Razumkova, A.V. Ruseykina, O.Yu. Mitroshin, V.O. Andreev. Fazovie ravnovesiya $\mathrm{v}$ sistemax sulfidov 3d-, 4f-elementov. (RIO URO RAN, Ekatirinburq, 2015. (In Russian).

[15] M.B. Babanly, E.V. Chulkov, Z. S. Aliev, A.V. Shevel'kov, I. R. Amiraslanov, Russ. J. Inorg. Chem. 62(13), 1703 (2017) (https://doi.org/10.1134/S0036023617130034).

[16] S.Z.Imamaliyeva, D.M. Babanly, D.B. Tagiev, and M.B. Babanly. Russ. J. Inorg. Chem, 63(13), 1703 (2018) (https://doi.org/10.1134/S0036023618130041).

[17] M.B. Babanly, L.F. Mashadiyeva, D.M. Babanly, S.Z. Imamaliyeva, D.B. Taghiyev, Y.A. Yusibov, Russian J. Inorg.Chem. 64(13), 1649 (2019) (https://doi.org/10.1134/S0036023619130035).

[18] T.B. Massalski. Binary alloys phase diagrams, second edition. (ASM International, Materials park, Ohio, 1990).

[19] Diagrammi sostoyaniya dvoynikh metallicheskikh system. Ed. Lyakishev N.P. (Mashinostroenie, Moscow, v.2, 1997). 
[20] O. Kubaschewski, C.B. Alcock. P.J. Spencer, Materials Thermochemistry (Oxford; New York : Pergamon Press, 1993).

[21] V.S. Yunqman, Baza dannix termicheskix constant veshestv. Elektronnaya versiya pod. red. 2006 q., http://www.chem.msu.su/cgi-bin/tkv.

[22] K.A. Sharifov, Z.Sh. Karaev, T.Kh. Azizov, Izv Akad. Nauk SSSR, Neorg. Mater. 3(4), 719 (1967).

[23] V.P. Vasiliev, V.I. Goryacheva, Y.I. Gerasimov, T.S. Lazareva, Bulletin of Moscow. University. Ser. Chim. 21(4), 339 (1980).

[24] K.C. Mills, Thermodynamic Data for Inorganic Sulphides, Selenides, and Tellurides (Butter-worth, London 1974).

[25] V.P. Vassiliev, $\quad$ V.A. Lysenko, Electrochimica $\quad$ Acta $\quad 222, \quad 1770$ (https://doi.org/10.1016/j.electacta.2016.11.075).

[26] V.P. Vassiliev, V.A. Lysenko, M. Gaune-Escard, Pure Appl.Chem. 91(6), 879 (2019) (https://doi.org/10.1515/pac-2018-0717).

[27] I.F. Mekhdiyeva, Fizika, 3, 25 (2019).

[28] S.Z. Imamalieva, D.M. Babanly, T.M. Gasanly, D.B. Tagiev, and M.B. Babanly, Russian Journal of Physical Chemistry A, 92(11), 2111 (2018) (https://doi.org/10.1134/S0036024418110158).

[29] D.M. Babanly, L.F. Mashadieva, M.B. Babanly, Inorg. Mater. 53(5), 519 (2017)(https://doi.org/10.1134/S002016851705003X).

[30] D.M. Babanly, G.M. Velieva, S.Z. Imamaliyeva, M.B. Babanly, Russ. J. Phys. Chem. A 91(7), 1170 (2017) (https://doi.org/10.1134/S0036024417070044).

[31] S.Z. Imamaliyeva, T.M. Gasanly, M.A. Mahmudova, F.M. Sadygov, Physics, XXII(4), 19 (2017).

[32] Y.I. Jafarov, S.A. Ismaylova, Z.S. Aliev, S.Z. Imamaliyeva, Y.A. Yusibov, M.B. Babanly, CALPHAD 55, 231 (2016) (https://doi.org/10.1016/j.calphad.2016.09.007).

[33] D. M. Babanly, I.M. Babanly, S.Z. Imamaliyeva, V.A. Gasimov, A.V. Shevelkov, J.Alloys. Compd 590, 68 (2014) (https://doi.org/10.1016/j.jallcom.2013.11.223).

[34] V. Vassiliev, W. Gong, Electrochemical Cells with the Liquid Electrolyte in the Study of Semiconductor, Metallic and Oxide Systems. In. Electrochemical Cells - New Advances in Fundamental Researches and Applications. Ed.Yan Shao, (IntechOpen, 2012).

[35] A.G. Morachevskij, G.F. Voronin, V.A. Gejderikh, I.B. Kuczenok, Elektrokhimicheskie metody issledovaniya v termodinamike metallicheskikh sistem (ICzK. Akademkniga, 2003).

[36] M.B. Babanly, Yu.A. Yusibov, Elektrokhimicheskie metody v termodinamike neorganicheskikh sistem (ELM, Baku, 2011).

[37] M.B. Babanly, Y.A. Yusibov, N.B. Babanly, The EMF method with solid-state electrolyte in the thermodynamic investigation of ternary Copper and Silver Chalcogenides. In. Electromotive force and measurement in several systems. Ed.S.Kara. (Intechweb.Org, 2011).

[38] A.N. Kornilov, L.B. Styopina, V.A. Sokolov, Russian J. Phys.Chem. 46(11), 2974 (1972).

[39] I. Barin, Thermochemical Data of Pure Substances, Third Edition, (VCH, 2008).

[40] A.T. Dinsdale, Calphad 15(4), 317 (1991) (https://doi.org/10.1016/0364-5916(91)90030-N).

\title{
С.З. Імамалієва, І.Ф. Мехдієва, Д.Б. Тагхієв, М.Б. Бабанли \\ Дослідження термодинаміки телуридів ербію методом електрорушійних сил (ЕРС)
}

\author{
Інститут каталітичної та неорганічної хімї ім. акад. М. Нагієва НАН Азербайджану, \\ Баку, Азербайджан, samira9597a@gmail.com
}

\begin{abstract}
У роботі подано результати термодинамічного дослідження системи Er-Те методом електрорушійних сил (ЕРС) в інтервалі температур $300-450$ К. 3 ЕРС-вимірювань концентрації комірок відносно електродів Er та ErTe, визначено часткові термодинамічні функції ErTe та Er у сплавах, на основі яких обчислюються стандартні термодинамічні функції утворення та стандартні ентропії проміжних сполук $\mathrm{ErTe}_{3}, \mathrm{Er}_{2} \mathrm{Te}_{3}$ та ErTe. Проведено порівняльний аналіз отриманих даних із літературними.
\end{abstract}

Ключові слова: фазова діаграма, телуриди ербію, метод ЕРС, термодинамічні функції. 